\title{
Biomedical HIV Prevention
}

\author{
Gita Ramjee and Claire Whitaker \\ HIV Prevention Research Unit, South African Medical Research Council \\ South Africa
}

\section{Introduction}

In 2009, an estimated 33.3 million adults and children worldwide were living with HIV, while 2.6 million were newly infected that year (UNAIDS, 2010). The epidemic most severely affects sub-Saharan Africa, where 22.5 million people live with the virus, and 1.8 million were newly infected in 2009 (UNAIDS, 2010). The predominant mode of HIV transmission in this hardest hit area is heterosexual intercourse, with young women particularly vulnerable to acquisition of the virus (Laga et al., 2001), a result of intersecting biological, social and cultural vulnerabilities (Coovadia et al., 2009; Hladik \& Hope, 2009).

Although initially considered a fatal diagnosis, HIV is fast becoming a chronic disease, manageable through the use of antiretroviral (ARV) medications. Under good health-care conditions, people living with HIV may now enjoy a life-span that is not significantly different from that of an uninfected person, even without ARV treatment (van Sighem et al., 2010).

Over the past 25 years since the identification of the causative agent of HIV, researchers have investigated many methods for the prevention of acquisition of the virus. It has become increasingly clear that a combination HIV prevention approach to combating the epidemic will be necessary, since no single intervention has yet been shown to have more than approximately $60 \%$ effectiveness in preventing infection (Klausner et al., 2008; Vermund et al., 2009). Biomedical prevention encompasses the use of medical treatments such as ARVs for prevention or post-exposure prophylaxis, barrier methods such as male and female condoms, procedures such as medical male circumcision or other methods to reduce the chance of transmission of HIV (Padian et al., 2008). Rather than dichotimising the response to the epidemic into separate biomedical and behavioural interventions, the most effective intervention is likely to incorporate both behavioural change and widespread provision of one or more biomedical prevention options for both men and women.

\section{Biomedical HIV prevention technologies}

\subsection{Vaccines}

Although vaccines may appear to be a ubiquitous facet of modern medical care, their development has required prolonged experimentation in several cases. The earliest and most famous vaccination experiment is perhaps Edward Jenner's deliberate infection in 1796 of a young boy with cowpox which conferred protection against the related, but much more deleterious smallpox (Dunn, 1996). Later in 1885, Louis Pasteur developed a post-exposure 
rabies anti-toxin which he also called a vaccine (Hoenig, 1986), thus broadening the definition of the term to include any applied substance which induced an immune response and conferred protection against subsequent infection (Atkinson et al., 2002). Vaccine development and production continued apace from that point onwards, although some diseases have proved more amenable to development of a vaccine than others. For example, although the causative agent of poliomyelitis was identified in 1908, an effective vaccine was not developed until 1955, an elapsed time of 47 years; it took 105 years to develop a vaccine against typhoid subsequent to identification of the causative organism, while the elapsed times to vaccine for Haemophilus influenza and pertussis were 92 years and 89 years respectively (Markel, 2005). Comparatively quicker has been the 16 year developmental pathway to a vaccine against hepatitis B (Markel, 2005).

Vaccines are generally formulated in the following ways:

- $\quad$ attenuated (live organisms which have lowered or disabled virulence)

- conjugate (combination of antigenic substances)

- $\quad$ killed (heat or chemically destroyed whole organism)

- inactivated toxoid (organismal products which would normally produce illness)

- $\quad$ subunit (specific fragments of the organism of interest)

Successful vaccines have been developed against viruses which follow a particular course of infection: a certain degree of initial replication and dissemination after infection is followed by migration to the target organ and the development of illness (Johnston \& Fauci, 2007). Should previous exposure to viral antigens have occurred, an endogenous immune reaction can occur, preventing the development of illness (Johnston \& Fauci, 2007). This response has two broad components: humoral and cellular. The humoral response involves the production of antibodies which neutralise the virus and prevent new infection of cells, while the cellular response recruits specific CD8+ cytotoxic $\mathrm{T}$ lymphocytes to destroy virally infected cells (Markel, 2005). The classic approach to vaccine design has been to elicit the production of high levels of neutralising antibodies which prevent the establishment of infection in target cells or organs (Johnston \& Fauci, 2007).

The search for an effective HIV vaccine has been hampered by the high genetic plasticity of HIV and its ability to escape the effects of neutralising antibodies through conformational shielding of vulnerable antigenic sites on the HIV envelope protein (Richman et al., 2003; Burton et al., 2004). HIV is able to establish a pool of latently infected cells in the early stages of infection (Chun et al., 1998), a feature of the infectious process which complicates the development of an effective vaccine, since infection in latent cells provides a reservoir of infection which cannot be cleared by the neutralising antibody response. In HIV infection, the natural production of neutralising antibodies only occurs weeks to years after the initial infecting event (Wyatt \& Sodroski, 1998; Johnston \& Fauci, 2007), and even then, the constant mutation of the virus renders the antibodies ineffective (Johnston \& Fauci, 2008). The approach in the context of HIV vaccines may have to be modified towards the elicitation of T-cell responses rather than neutralising antibodies. This may not provide protection against infection, but will rather reduce the viral load set point and early viral load should the vaccine recipient become infected, with associated positive effects on progression to AIDS or length of time to initiation of ARV therapy (Amara et al., 2001; Letvin et al., 2006; Padian et al., 2008). Reduction of viral load set point and early viral load could also have important implications for transmission, since most transmission events are hypothesised to occur during acute infection of the transmitting partner, due to high viral load levels (Pilcher et al., 2004). 
HIV vaccines strategies have included live attenuated vaccines, inactivated vaccines, viruslike particles, subunit vaccines, naked DNA and live recombinant vaccines (Girard et al., 2006). Of these, only subunit vaccines (gp120 protein) and live recombinant vaccines (MRKAd5 HIV-1 gag/pol/nef and ALVAC) have advanced to late stage human clinical testing, the results of which will be summarised below.

Five candidate vaccines have advanced to late stage safety and/or efficacy testing (see table 1). Two, the STEP and Phambili trials, were of the MRKAd5 HIV-1 gag/pol/nef vaccine (Buchbinder et al., 2008; Gray et al., 2008); these vaccines utilised a mixture of three adenovirus vectors expressing the gag, pol and nef genes of HIV. Gag, pol and nef were selected for inclusion in the vaccine as they are commonly recognised during natural HIV infection, and are conserved across HIV clades (thus potentially providing protection against more than one HIV sub-type) (Buchbinder et al., 2008). Two trials were of rgp120 vaccines (Flynn et al., 2005; Pitisuttithum et al., 2006); rgp120 is a purified recombinant form of an HIV outer envelope protein, which, it was hoped, would elicit an effective immune response in vaccine recipients. A combination prime (ALVAC-HIV) + boost (AIDSVAX B/E) strategy was also investigated in a large trial in Thailand (known as RV 144) (Rerks-Ngarm et al., 2009). The ALVAC component comprised a recombinant canarypox vector genetically engineered to express subtype B HIV-1 Gag and Pro proteins and gp120 from subtype CRF01_AE linked to the transmembrane anchoring portion of gp41. AIDSVAX consisted of a combination of gp120 proteins from subtype B and $\mathrm{E}$ viruses. The hope of the prime + boost technique was that both T-cell and antibody responses could be generated by the vaccine, as opposed to antibody responses alone (Hu et al., 1991), the effectiveness of which is compromised by the innate behaviour of HIV (described in the preceding paragraph).

\begin{tabular}{|c|c|c|c|}
\hline Vaccine & Study location & $\begin{array}{l}\text { Approximate sample } \\
\text { size }\end{array}$ & Result \\
\hline $\begin{array}{l}\text { B/B rgp120 (Flynn et } \\
\text { al., 2005) }\end{array}$ & $\begin{array}{l}\text { North America; The } \\
\text { Netherlands }\end{array}$ & $5000+$ & $\begin{array}{l}\text { No significant effect } \\
\text { on HIV acquisition }\end{array}$ \\
\hline $\begin{array}{l}\text { MRKAd5 HIV-1 } \\
\text { gag/pol/nef (B) } \\
\text { (Buchbinder et al., } \\
\text { 2008) } \\
\text { MRKAd5 HIV-1 }\end{array}$ & $\begin{array}{l}\text { North America; South } \\
\text { America; Caribbean, } \\
\text { Australia }\end{array}$ & 3000 & $\begin{array}{l}\text { No significant effect } \\
\text { on HIV acquisition, } \\
\text { possible harm }\end{array}$ \\
\hline \multicolumn{2}{|c|}{$\begin{array}{l}\text { gag/pol/nef (B) (Gray South Africa } \\
\text { et al., 2008) }\end{array}$} & 801 & Trial stopped early \\
\hline \multicolumn{2}{|c|}{ AIDSVAX B/E rgp120 Thailand } & 2500 & $\begin{array}{l}\text { No significant effect } \\
\text { on HIV acquisition }\end{array}$ \\
\hline \multicolumn{3}{|c|}{$\begin{array}{l}\text { ALVAC-HIV } \\
\text { (vCPI521) HIV-1 }\end{array}$} & \\
\hline \multicolumn{2}{|c|}{$\begin{array}{l}\text { gag/pro (B) \& } \\
\text { rgp120/gp41 (E) primeThailand } \\
+ \text { AIDSVAX B/E (rgp } \\
\text { 120) boost (Rerks- } \\
\text { Ngarm et al., 2009) }\end{array}$} & $16000+$ & $\begin{array}{l}\text { Modest protective } \\
\text { effect against } \\
\text { acquisition of HIV }\end{array}$ \\
\hline
\end{tabular}

* " $B$ " and " $E$ " in Vaccine column refer to HIV clades that vaccine products were derived from.

Table 1. Advanced stage safety and efficacy trials of HIV vaccines 
Of these trials, the STEP, Phambili and rgp120 trials, produced "flat" results, indicating neither benefit nor harm of the interventions in terms of HIV prevention. Both the STEP and Phambili trials were prematurely terminated due to concerns over safety, while both of the rgp120 trials were completed. However, the recent RV 144 trial provided tantalising evidence of a significant positive effect for preventing the acquisition of HIV (Rerks-Ngarm et al., 2009). The effect was modest, however, and further research will be necessary to expand on several questions raised by the study results: vaccine efficacy was found to decrease over the first year after vaccination, and may have been greater in persons at lower risk (Rerks-Ngarm et al., 2009). Overall, the results of these advanced stage trials tend to indicate that more pre-clinical studies should be undertaken to gain improved understanding of immune response to the virus before products are tested in large-scale human clinical trials. A significant limitation of the vaccine trials conducted to date has been that the vaccines are derived from less prevalent HIV subtypes: as shown in table 1, most contained derivatives of subtype B or E virus, while subtype $C$ is most prevalent in Africa, the region with the worst HIV epidemic (UNAIDS, 2010).

As with most biomedical technologies, vaccines are unlikely to be $100 \%$ effective. Even if we reduce self-reported adherence challenges by using vaccines, consumer and epidemiological models suggest that individual perception of protection by the vaccine is likely to increase risk behaviour by $25 \%$ to $50 \%$ (Newman et al., 2004; Crosby \& Holtgrave, 2006). Behavioural changes will be necessary to demonstrate effectiveness of the vaccine.

\subsection{Medical male circumcision}

Medical male circumcision has been regarded as one of the success stories in the battle against HIV over the past decade. Based on ecological and observational evidence (Weiss et al., 2000) it was hypothesised that male circumcision had a significant effect on the prevalence of HIV. There are several possible causes for this effect: circumcision removes the foreskin, thus resulting in keratinisation of the underlying epithelium. The nonkeratinized inner epithelium is more susceptible to infection by HIV than the keratinised outer epithelium of the foreskin (Patterson et al., 2002), which could provide a point of entry for the virus. However, some evidence contradicting this hypothesis has recently been presented: Dinh et al (Dinh et al., 2010) found no significant difference between the degree of keratinisation of the inner and outer foreskin in 16 donor tissue samples; those authors and others (Kigozi et al., 2009) suggest that the surface area of the foreskin may play a more important role in susceptibility to HIV - the larger the foreskin, the higher the risk of acquiring the virus. The proliferation of HIV target cells (such as Langerhans cells) in the foreskin may also explain the reduction in vulnerability to HIV following its removal (McCoombe \& Short, 2006). Circumcision also reduces the risk of men acquiring certain other sexually transmitted infections such as chancroid, syphilis (Weiss et al., 2006), human papillomavirus (HPV) and herpes simplex virus type 2 (HSV2) (Tobian et al., 2009) which may themselves increase the risk of infection with HIV (Fleming \& Wasserheit, 1999).

An earlier meta-analysis of studies conducted in sub-Saharan Africa which included circumcision as a potential risk factor found that the evidence for an effect was compelling, but also noted significant heterogeneity between the studies, which the authors concluded indicated that effects might vary between populations (Weiss et al., 2000). Despite this, three large-scale clinical trials monitoring the incidence of female-to-male transmission of HIV following circumcision showed strong evidence for a reduction in risk of acquisition of HIV ranging from $48 \%$ to $61 \%$ (Auvert et al., 2005; Bailey et al., 2007; Gray et al., 2007). This level 
of protection was projected to potentially be capable of preventing 2 million new HIV infections and 0,3 million deaths in the ten years after 2006 (Williams et al., 2006), and has even been described as "as good as the HIV vaccine we've been waiting for" (Klausner et al., 2008). Despite the positive benefits for men, male circumcision does not appear to protect women from acquiring HIV from an already infected man (Wawer et al., 2009). This may be due to resumption of sexual activity prior to complete wound healing, or risk compensation (an increase in risky behaviour owing to perceptions of the protective effect of the intervention) (Wawer et al., 2009). Medical male circumcision has, however, been found to reduce the prevalence and incidence of HPV infections in female partners (Wawer et al., 2011). Safer sex counselling and condom provision are recommended as companions to circumcision services.

Despite clear evidence for efficacy of this intervention in preventing female-to-male HIV transmission, evidence for effectiveness in preventing male-to-male transmission is less certain - although some evidence suggests that circumcision may protect against HIV acquisition in men who prefer the insertive role, overall, circumcision has not been found to protect against HIV infection in men who have sex with men (MSM) (Millett et al., 2008; Templeton et al., 2009). Further research on the potential role of circumcision in HIV prevention for MSM is warranted.

Scaling up of this intervention has been challenging due to lack of health infrastructure capacity in countries most in need of this intervention, which impacts on both safety and cost-effectiveness. In addition, cultural beliefs may hinder the uptake of this intervention in many societies worldwide.

\subsection{Barrier methods for HIV prevention}

Condoms provide an effective physical barrier to HIV infection, the evidence for which is consistent and compelling (Carey et al., 1992; Lytle et al., 1997; Pinkerton \& Abramson, 1997; Weller \& Davis-Beaty, 2002). In addition, condoms also reduce the transmission of many other sexually transmitted infections such as Chlamydia trachomatis, syphilis, HSV2 and Neisseria gonorrhoeae (Holmes et al., 2004), infection with which may in turn increase susceptibility to HIV infection (Wasserheit, 1992). In vitro testing of the male latex condom has shown that in a worst case scenario, use of a condom is $10^{4}$ times better at preventing semen transfer than not using a condom at all (Carey et al., 1992).

Male condoms have been pivotal in HIV prevention programs since HIV was first identified. When correctly and consistently used, condoms are estimated to reduce the per contact probability of male-to-female infection by as much as 95\% (Pinkerton \& Abramson, 1997). Among the general population in Rakai, Uganda, consistent condom use was associated with reduced HIV incidence (Ahmed et al., 2001), while meta-analysis of condom use among sero-discordant couples has shown that consistent use results in an incidence rate for male-to-female transmission of 0.9 per 100 person years compared with 6.8 per 100 person years in persons who never used condoms (Davis \& Weller, 1999). Davis and Weller also found in their review that breakage rates varied between $0.5 \%$ and $6.7 \%$, while rates of slippage ranged from $0.1 \%$ to $16.6 \%$ (Davis \& Weller, 1999). Despite widespread condom promotion, their use is often incorrect and inconsistent (Foss et al., 2004), which reduces their effectiveness. Usage has been found to vary by partner type, with condoms more frequently used with casual or short-term partners, but not with marital or long-term partners (Maharaj \& Cleland, 2004; Chimbiri, 2007; Hargreaves et al., 2009). In contexts in which multiple concurrent partnering may be normalised, this pattern of behaviour puts the 
partners at risk of both contracting and rapidly transmitting HIV (Halperin \& Epstein, 2007; Epstein, 2008).

Uganda has served as an example of the possible success of an aggressive "ABC" approach - abstinence, behavioral change and condom use campaigns can be successful in curbing HIV infections (Stoneburner \& Low-Beer, 2004). This has also been demonstrated by the "100\% condom program" in Thailand (Rojanapithayakorn \& Hanenberg, 1996; Park et al., 2010), which sought to encourage condom use at every commercial sexual encounter and was also accompanied by an extensive advertising campaign. However, in many countries gender relations, social inequality and economic dependence do not allow young women to negotiate safe sex (with condoms) with their partners (Laga et al., 2001; Hunter, 2007; Ramjee et al., 2008). Hence, other woman-initiated prevention options are urgently needed (Stein, 1990).

The efficacy of the female condom in preventing transmission of STIs has provided support for its hypothetical efficacy in preventing HIV, although no clinical trials specifically to test this have been conducted (Vijayakumar et al., 2006). Early testing showed that the female condom was impermeable to both HIV and cytomegalovirus (Drew et al., 1990). Measures of semen exposure during female condom use have been found to vary between 5 and 19\% when no problems were reported, but this rose to between 17 and $30 \%$ if a problem was reported during use (Macaluso et al., 2003). Complete protection from semen exposure occurred in $79-93 \%$ of sex acts. In that study, $83 \%$ of women who used one or more female condoms reported experiencing a problem with the condom, indicating that mechanical and acceptability challenges may seriously limit the uptake of the female condom. However, the incidence of problems did decline over time, suggesting that greater experience reduced problems with usage (Macaluso et al., 2003). Incidence of semen exposure has also been found to vary with both couple- and intercourse-specific features, indicating that achieving consistent results across a population may prove difficult unless intensive counselling and education accompany distribution of the female condom (Lawson et al., 2003). The female condom is relatively more expensive than male condoms as it is made of polyurethane rather than latex, but could in turn prove highly cost effective when implemented in a strategic public health programme targeting users at high risk of contracting HIV (Warren \& Philpott, 2003). Despite evidence of demand for the female condom, production levels remain low, and the price accordingly high (Peters et al., 2010), an untenable situation for such a promising prevention method. It may be possible to circumvent the problems of cost and availability by re-using female condoms - washing, drying and re-lubricating them between in vivo uses has been shown not to affect the burst and seam strength up to eight washes, while the breakage rate associated with multiple washing and re-use was slightly lower than that found in the case of single use followed by washing. While it is preferable to use a new female condom for each instance of intercourse, re-use may be possible where a new female condom cannot be obtained (Beksinska et al., 2001).

The urgent need to develop woman-initiated methods which can be used covertly led to testing of the HIV prevention potential of cervical barriers. Observational data suggested that covering the cervix with a diaphragm may reduce the risk of HIV (Padian et al., 2007). The epithelium of the cervix is composed of a comparatively thinner and more delicate unilayer of columnar epithelium, in contrast to the stratified squamous epithelium of the vagina, which may be more robust in resisting infection (Hladik \& Hope, 2009). The cervix is also rich in HIV target cells - particularly in the transformation zone, which is richly supplied with macrophages and CD4+ T cells (Pudney et al., 2005). However, a randomized 
controlled trial (RCT) testing the hypothesis that covering the cervix may protect against HIV infection failed to show effectiveness (Padian et al., 2007) - the HIV seroconversion rates were similar in diaphragm users and control participants. Some challenges experienced during implementation of the trial included low adherence and risk compensation among diaphragm users. It is proposed that diaphragms could be an additional tool in the "HIV prevention tool-box" and used as a delivery device for products such as microbicides (see below) (Padian et al., 2007). Despite the lack of evidence for efficacy in preventing HIV infection, the diaphragm has shown efficacy in prevention of gonococcal infections (Ramjee et al., 2008).

\subsection{Microbicides}

Microbicides are intravaginal products designed to be used discreetly by women to prevent HIV; the products are formulated in a variety of ways, including gels, films, tablets and as intravaginal rings (IVR) (Ndesendo et al., 2008; Buckheit Jr et al., 2010). Although a variety of dosage forms have been developed, the gel and IVR have lately come to dominate the development pipeline. The development of microbicides was prompted by Zena Stein's call for a woman-initiated means of preventing HIV infection, in recognition of the fact that men had ultimate control of the (then) only biomedical means of preventing HIV infection - the male condom (Stein, 1990).

The first generation of microbicides to be tested in large-scale clinical trials were surfactant in nature - nonoxynol-9 (N9) was one of the first compounds to be tested. Surfactant products act by non-specifically disrupting biological membranes resulting in organism lysis. This spermicide was found to have in vitro anti-HIV activity (Polsky et al., 1988; Jennings \& Clegg, 1993) and prevented infection of cats by feline immunodeficiency virus (Moench et al., 1993) and macaques with simian immunodeficiency virus (SIV)(Miller et al., 1992), but failed to prevent HIV infection in women (van Damme et al., 2002). N9 was found to disrupt the epithelium of the vagina in women who made frequent use of the product, thus enhancing rather than protecting against HIV infection. This result encouraged the adoption of more rigorous and extensive pre-clinical studies in an attempt to prevent the advancement into human stage testing of potentially harmful products. N9 was succeeded by another surfactant gel product called SAVVY, which although safe, was not conclusively found to be of utility in preventing HIV infection (Peterson et al., 2007; Feldblum et al., 2008).

Alongside the surfactants, the following polyanionic compounds were also tested as microbicidal agents: cellulose sulphate, Carraguard and PRO 2000. Polyanions interfere with the attachment of HIV to target cells - PRO 2000, for example, binds to the viral coat protein gp120, and also to host cellular receptors such as CD4 and CXCR4 (Huskens et al., 2009). However, all three polyanions (as well as the surfactants) were non-specific to HIV, a characteristic which is now thought to have had a profound impact on the utility of the compounds for the prevention of infection. Although Carraguard and PRO 2000 were both found to be safe to use, they had no discernable effect on HIV infection (SkolerKarpoff et al., 2008; Abdool Karim et al., 2011), while cellulose sulphate may have increased the risk of infection in a similar manner to that of N9 - by disrupting tight junctions between cells and increasing viral replication (Mesquita et al., 2009). However, Carraguard has been found to have utility in preventing infection with HPV (Marais et al., 2010) - the causative agent of cervical cancer (Ho et al., 1995; Nobbenhuis et al., 1999), and further investigations for this application are underway. Gels which are found to be safe may also be used as carriers for other compounds - the combination of Carraguard and 
the ARV MIV-150 has shown some efficacy in preventing SHIV-RT infection in macaques (Aravantinou et al., 2010).

Recently, there has been a major leap forward in the microbicide field, with the use of ARVbased agents for HIV prevention. The Centre for the AIDS Programme of Research In South Africa (CAPRISA) 004 safety and effectiveness study compared 1\% tenofovir gel with a placebo, and found that the active gel reduced HIV infections by $39 \%$ overall, and by $54 \%$ in highly adherent trial participants (Abdool Karim et al., 2010). This result is at the forefront of a major sea change in the microbicide field away from non-specific compounds and towards the use of specific ARV drugs for application prior to exposure to HIV. Trials are currently planned to confirm the effect of $1 \%$ tenofovir gel, and several trials are ongoing to test the safety and/or efficacy of other ARVs such as dapivirine and UC781 (see table 2 below).

\begin{tabular}{|c|c|c|c|}
\hline Study /Phase & Location & Population & Candidate substance \\
\hline $\begin{array}{l}\text { VOICE (MTN 003) } \\
\text { Phase IIb, safety and } \\
\text { effectiveness }\end{array}$ & $\begin{array}{l}\text { Malawi, South Africa, } \\
\text { Uganda, Zimbabwe }\end{array}$ & $\begin{array}{l}5,000 \text { heterosexual } \\
\text { women }\end{array}$ & $\begin{array}{l}\text { Tenofovir gel; oral } \\
\text { TDF; oral TDF/FTC }\end{array}$ \\
\hline $\begin{array}{l}\text { IPM 014A } \\
\text { Phase I/II, safety }\end{array}$ & $\begin{array}{l}\text { Kenya, Malawi, } \\
\text { Rwanda, South Africa }\end{array}$ & 320 women & Dapivirine vaginal gel \\
\hline $\begin{array}{l}\text { IPM 014B } \\
\text { Phase I/II, safety }\end{array}$ & South Africa & 320 women & Dapivirine vaginal gel \\
\hline $\begin{array}{l}\text { IPM } 020 \\
\text { Phase I/II, safety }\end{array}$ & United States & 180 women & Dapivirine vaginal gel \\
\hline $\begin{array}{l}\text { IPM } 015 \\
\text { Phase I/II, safety }\end{array}$ & $\begin{array}{l}\text { South Africa } \\
\text { (ongoing), Kenya, } \\
\text { Malawi, Rwanda, } \\
\text { Tanzania, Zambia } \\
\text { (planned) }\end{array}$ & 280 women & $\begin{array}{l}\text { Dapivirine vaginal } \\
\text { ring }\end{array}$ \\
\hline $\begin{array}{l}\text { IPM } 013 \\
\text { Phase I, P/K }\end{array}$ & Belgium & 48 women & $\begin{array}{l}\text { Dapivirine vaginal } \\
\text { ring }\end{array}$ \\
\hline $\begin{array}{l}\text { Pilot Study } \\
\text { Phase I }\end{array}$ & United States & 15 women & UC-781 gel \\
\hline
\end{tabular}

Table adapted from Alliance for AIDS Vaccine Advocacy Coalition website at www.avac.org accessed March 29, 2011 FTC - emtricitabine; TDF - tenofovir disoproxil fumarate

Table 2. Ongoing ARV-based microbicide trials

The ARV-based microbicides in Table 2 are all reverse transcriptase inhibitors (RTIs), although of two different classes. Tenofovir is a nucleoside reverse transcriptase inhibitor or "chain terminator" which interferes with the synthesis of the viral DNA by interpolation into the growing strand. Both dapivirine and UC-781 are non-nucleoside reverse transcriptase inhibitors (NNRTIs) which bind to a non-active site on reverse transcriptase, inducing a conformational change which prevents further activity of the enzyme (D'Cruz \& Uckun, 2006). Other prospective ARV-based microbicides may include maraviroc (a cell entry inhibitor) (Fletcher et al., 2010; Herrera et al., 2010), protease inhibitors (Evans et al., 2010) and other NNRTIs such as MIV-150 (Kenney et al., 2011).

Recent innovations in microbicide delivery have included the development of intravaginal rings (IVRs). These rings are similar to those currently marketed for contraceptive use, but 
have instead as their active ingredient an antiretroviral agent. The rings have been formulated in two ways - as matrix or reservoir types. In the matrix type, the active ingredient is homogenously distributed throughout the ring material, while in the reservoir type, a central core containing the ARV is surrounded by an unmedicated outer layer (Malcolm et al., 2010). Matrix type IVRs may have a less favourable drug release profile than the reservoir type, since the release of the drug is less controlled, resulting in an early spike in concentration. The addition of rate controlling layers may assist in minimising this characteristic (Malcolm et al., 2010). Most IVRs are made of silicone elastomer (eg. polydimethylsiloxane) or thermoplastic elastomer (eg. poly[ethylene vinyl acetate] and segmented polyurethane) (Malcolm et al., 2010). Formulation of IVRs both with and without contraceptives will provide women with the option of preventing acquisition/transmission of HIV without affecting fertility - a feature which is particularly important in contexts where fertility is highly valued.

Although microbicides were initially proposed for vaginal use, there has recently been an increase in research on microbicides for rectal application, since it is recognised that this is a significant route of exposure to HIV infection for both women and men who have sex with men (Ramjee et al., 2010). The development of microbicides for application to the rectum has resulted in research comparing the effect of microbicides on the vaginal and rectal mucosa which has shown that the rectal mucosa may be relatively more delicate (Patton et al., 2009). Vaginal microbicides should not be assumed to be safe for rectal use. Future work on rectal microbicides will require specific in vitro and animal models to assess the impact of the products on the target tissue type.

Challenges in the clinical trials of microbicides have included lack of appropriate animal models to assess safety prior to human trials, high pregnancy rates (women are taken off the product when pregnant), products with low HIV specificity, and achieving high adherence to the product by trial participants (Ramjee et al., 2010). The promising effectiveness demonstrated by an ARV-based microbicide has re-invigorated the field (Abdool Karim et al., 2010). However, these products remain unlikely to be $100 \%$ effective, hence correct and consistent use of additional prevention options may be required.

\subsection{Oral antiretroviral therapy for prevention}

Development and use of ARV agents has had a significant impact on improving lifespan and quality of life of people living with HIV. These agents have also played a groundbreaking role in prevention of mother to child transmission (MTCT) (Connor et al., 1994) with MTCT in the developed world almost eradicated owing to this success. The use of ARVs for prevention of MTCT has been shown to be both feasible and cost effective (Chigwedere et al., 2008) - but treatment may not be available to women living in less developed countries.

The success of prevention of MTCT suggests that antiretroviral therapy (ART) could be used as a chemoprophylactic method to prevent sexual HIV transmission due to its ability to suppress viral load and viral replication both prior to and post exposure to HIV. There is evidence that post-exposure prophylaxis (PEP) can reduce the risk of acquisition of HIV (Mackie \& Coker, 2000). Research into ART for pre-exposure prophylaxis (PrEP) has gained momentum recently with several trials in various population groups under way in many countries. All these trials (see Table 3 ) have used the drug tenofovir disoproxil fumarate (TDF) or tenofovir disoproxil fumarate/emtricitabine (TDF/FTC) due to its good safety profile and infrequent side effects (Paxton et al., 2007). Tenofovir disoproxil fumarate is the 
prodrug form of tenofovir, a nucleotide reverse transcriptase inhibitor which prevents elongation of the transcribed HIV DNA by interpolation into the growing chain in place of adenosine 5'-monophosphate (Gilead, 2010). Emtricitabine functions in a similar manner and is the (-) enantiomer of a thio analog of cytidine (Gilead, 2008).

\begin{tabular}{|c|c|c|c|}
\hline Trial & Products & Population & Countries \\
\hline \multicolumn{4}{|l|}{ Phase IIb and III } \\
\hline $\begin{array}{l}\text { Parallel comparison of Tenofovir and } \\
\text { Emtricitabine/Tenofovir PrEP to prevent } \\
\text { HIV-1 acquisition within HIV-1 discordant } \\
\text { couples (Partners PrEP) }\end{array}$ & $\begin{array}{l}\text { TDF/FTC: Oral, } \\
\text { TDF: Oral }\end{array}$ & $\begin{array}{l}4700 \text { discordant } \\
\text { heterosexual } \\
\text { couples }\end{array}$ & $\begin{array}{l}\text { Kenya, } \\
\text { Uganda }\end{array}$ \\
\hline $\begin{array}{l}\text { Safety and efficacy of daily tenofovir to } \\
\text { prevent HIV infection (Bangkok Tenofovir } \\
\text { Study }\end{array}$ & TDF: Oral & $\begin{array}{l}2400 \text { IV drug } \\
\text { users }\end{array}$ & Thailand \\
\hline $\begin{array}{l}\text { Safety and effectiveness study of tenofovir } \\
1 \% \text { gel, tenofovir disoproxil fumarate tablet } \\
\text { and emtricitabine/tenofovir disoproxil } \\
\text { fumarate tablet for the prevention of HIV } \\
\text { infection in women (VOICE/MTN 003) }\end{array}$ & $\begin{array}{l}\text { TDF/FTC:Oral } \\
\text { TDF: Oral } \\
\text { TDF: Gel }\end{array}$ & 5000 women & $\begin{array}{l}\text { South Africa, } \\
\text { Uganda, } \\
\text { Zimbabwe }\end{array}$ \\
\hline
\end{tabular}

Phase I and II

\begin{tabular}{|c|c|c|c|}
\hline Extended safety trial (PrEP in young MSM) & TDF: Oral & 99 young MSM & $\begin{array}{l}\text { United } \\
\text { States }\end{array}$ \\
\hline $\begin{array}{l}\text { Safety and efficacy of daily and oral } \\
\text { antiretroviral use for the prevention of } \\
\text { HIV infection in heterosexually active } \\
\text { young adults (TDF2) }\end{array}$ & TDF/FTC: Oral & $\begin{array}{l}1200 \\
\text { heterosexual } \\
\text { men and women }\end{array}$ & Botswana \\
\hline $\begin{array}{l}\text { IAVI E001 \& E002 } \\
\text { Phase I/II }\end{array}$ & $\begin{array}{l}\text { TDF/FTC: Oral } \\
\text { daily and coitally } \\
\text { dependent }\end{array}$ & $\begin{array}{l}150 \\
\text { serodiscordant } \\
\text { couples }\end{array}$ & $\begin{array}{l}\text { Kenya, } \\
\text { Uganda }\end{array}$ \\
\hline
\end{tabular}

Table adapted from Alliance for AIDS Vaccine Advocacy Coalition website at www.avac.org accessed 22 February 2011.

TDF/FTC: tenofovir disoproxil fumarate/emtricitabine; TDF: tenofovir disoproxil fumarate

Table 3. Oral pre-exposure prevention candidates in clinical trials

The results of the iPrEx trial of oral TDF/FTC showed that oral PrEP may be able to reduce HIV incidence among men who have sex with men (Grant et al., 2010). However, the effectiveness of the treatment is likely to be heavily influenced by the adherence of the persons taking the medication - low adherence among participants in the iPrEx trial may have affected the level of protection afforded by the study drugs (Grant et al., 2010). If consensus emerges that PrEP is safe and effective, there will be several challenges for wide-spread roll-out of the method to the population that needs it, including identifying the appropriate target population, monitoring of adherence and side-effects, and development of potential drug resistance. PrEP is unlikely to be $100 \%$ effective, so monitoring of adherence and risk compensation will be critical and will require behavioural intervention. 


\subsection{Treatment of Sexually Transmitted Infections}

Many observational studies have suggested that sexually transmitted infections (STIs), including HSV2, enhance HIV acquisition (Wasserheit, 1992; del Mar Pujades Rodríguez et al., 2002; Freeman et al., 2006). The mechanism by which infection is thought to be facilitated varies depending on the particular STI. Rebbapragada and Kaul (Rebbapragada \& Kaul, 2007) summarise five mechanisms by which STIs might enhance susceptibility to HIV: macro or micro-scale breach of the genital epithelium; alteration of the levels of innate immune proteins and/or mucosal environment; enhancing susceptibility to other genital infections; attraction of activated HIV target cells to the site of HIV exposure; and by increasing inflammation which in turn enhances HIV replication. Ulcerative STIs such as HSV2 and syphilis may facilitate HIV infection directly through discontinuities in the genital epithelium (Wasserheit, 1992), but may also have mechanisms in common with other non-ulcerative STIs such as gonorrhoea and Chlamydia trachomatis which are thought to facilitate infection both through micro-ulcerations and by increasing inflammation within the genital tract with subsequent proliferation of HIV target cells (Rebbapragada \& Kaul, 2007).

Treatment of STIs for prevention of HIV can include antibiotic or viral suppressive medications, or a combination of both.

Randomised controlled trials of STI treatment have found a significant reduction in HIV in only one instance - for a community randomised trial of syndromic treatment of bacterial infections in Mwanza, Tanzania (Grosskurth et al., 1995). Monthly provision of $1 \mathrm{~g}$ of azithromycin to female commercial sex workers in a RCT in Nairobi, Kenya did not result in a reduction in subsequent acquisition of HIV, although significant reductions in gonorrhoea, Chlamydia and Trichomonas vaginalis infections were noted (Kaul et al., 2004). A large scale community intervention with three arms (including an STI treatment arm) carried out near Masaka, Uganda, found that although the trial activities may have positively influenced sexual behaviour and incidence of certain STIs, no detectable influence on HIV was noted (Kamali et al., 2003). In a trial comparing the effects of intensive versus standard STI care and treatment, a lower but not significantly different HIV seroconversion rate was noted in participants randomized to the intensive care regimen (Ghys et al., 2001). Two recent largescale trials showed no evidence for an effect of HSV2 suppressive therapy on HIV acquisition (Celum et al., 2008; Watson-Jones et al., 2008). HSV2 suppressive therapy was also unable to prevent transmission of HIV from infected to uninfected partners, despite a reduction in their HIV viral load (Celum et al., 2010).

It has been proposed that STI treatment may only be effective in concentrated epidemics, and that the effectiveness of such interventions decreases with increasing generalization of the epidemic (Grosskurth et al., 2000). Despite overwhelming biological evidence for STI treatment as a potential HIV prevention option, efficacy has not been demonstrated in trials due to limitations in treatment approach, adherence and acceptability (Grosskurth et al., 2000; Lagakos \& Gable, 2008). This should not preclude the inclusion of effective STI treatment in HIV prevention plans, as this approach is important for preventing other significant causes of morbidity, and may also have the effect of normalising the need for safe sexual behaviour.

\subsection{Harm reduction for intravenous drug users}

Although the primary mode of HIV transmission in the world is heterosexual sex, there remain concentrated HIV epidemics among intravenous drug users (IDUs) in parts of Asia 
and South America, while the epidemic among IDUs in Europe and North America is declining (UNAIDS, 2010).

HIV may remain viable in blood residue in used needles and syringes for several weeks (Abdala et al., 1999), providing an efficient mechanism for transmitting virus between multiple individuals who re-use such equipment. Mechanisms introduced to reduce the incidence of HIV infection in this population include behavioral risk reduction (Copenhaver et al., 2006), clean needle and syringe exchange programs, and opioid substitution (Vlahov et al., 2010).

Although it is possible to clean needles with bleach for re-use (Shapshak et al., 1994; Abdala et al., 2001), greater success in lowering HIV risk has been achieved through needle exchange programs (NEPs). Such programs provide IDUs with sterile needles and syringes and promote other interventions such as referral to treatment programs. Although there is a lack of experimental data (Wodak \& Cooney, 2005), it is apparent that such programs impact on risky injection behavior and thus transmission of HIV and other infections (Holtzman et al., 2009). Ecological studies have shown that a reduction in HIV infections followed the introduction of combined opioid substitution therapy and needle and syringe exchange programs in the European Union and five middle and higher income countries (Wiessing et al., 2009); similarly, cities worldwide that have needle exchange programs have experienced a drop in HIV prevalence (Hurley et al., 1997; MacDonald et al., 2003).

Opioid substitution therapy is largely based on the provision of methadone or a buprenorphine/naloxone combination (Vlahov et al., 2010). Methadone is a synthetic compound, which, although differing in structure from morphine, also has significant analgesic effects (Toombs \& Kral, 2005). The drug may be administered by a variety of routes, but is most commonly applied orally or intravenously (Toombs \& Kral, 2005), with oral administration favored for use in opioid substitution therapy (Doweiko, 2009). Methadone has two primary properties which make it useful in treatment of opioid addiction: first, it ameliorates the discomfort associated with withdrawal from the illicit drugs, and second, oral doses block the craving for opioids (Doweiko, 2009). The use of methadone provides the opportunity for the IDU to resume a more normal life, but must be accompanied by other supportive interventions to promote behavior change and integration into mainstream society. Combination of methadone treatment with needle exchange programs may be the most effective intervention for lowering incidence of HIV and other infections among IDUs (Van Den Berg et al., 2007).

Buprenorphine in combination with naloxone is also used in the treatment of IDUs; buprenorphine is a long-acting derivative of the morphine alkaloid thebaine which blocks the effects of morphine with infrequent induction of physical dependence (Jasinski et al., 1978; Ruiz et al., 2007). Although buprenorphine has poor oral bioavailability, it was thought important that it not be intravenously administered to former IDUs due to their previous abuse of injection equipment; the drug is therefore formulated as an oral tablet, either alone or in combination with naloxone (Ruiz et al., 2007). The addition of naloxone is intended to reduce the potential for abuse of buprenorphine (known as treatment "diversion"), since intravenously administered naloxone precipitates unpleasant withdrawal symptoms (Mendelson et al., 1996); naloxone has poor oral bioavailability and few effects when taken via this route (Walsh \& Eissenberg, 2003).

Opioid substitution therapy has been shown to have significant positive effects in reducing HIV acquisition through reductions in both drug use and risky behaviors associated with 
injection drug use (Metzger et al., 1993; Metzger \& Navaline, 2003). Refinements to treatment regimens are on-going, including the investigation of the possibility of treatment in physician's offices (Gunderson \& Fiellin, 2008) (as opposed to in-program treatment) and contingent provision of treatment to be taken at home (Gerra et al., 2011).

\section{Conclusion}

Of the many trials of biomedical interventions to prevent sexual HIV acquisition completed, six to date have shown a statistically significant reduction in HIV incidence (three on male circumcision, one on STI control, one microbicide trial and one oral PrEP trial). Challenges encountered while testing these interventions included lack of appropriate animal models to measure safety and efficacy in pre-clinical testing (Dhawan \& Mayer, 2006; Buckheit Jr et al., 2010), lack of appropriate measures of adherence to product use by participants (nonvaccine trials) (Tolley et al., 2009), the confounding effect of heterosexual anal sex (Mâsse et al., 2009), high pregnancy rates (Mâsse et al., 2009), and generally falling HIV incidence rates in countries where these efficacy trials are conducted (Ramjee et al., 2008). It is now widely accepted that a single biomedical intervention is unlikely to be $100 \%$ effective in preventing HIV acquisition, and all will have the potential to be confounded by risk compensation, poor adherence, and acceptability issues. The potential effectiveness of many biomedical prevention interventions tested to date is undermined by risk compensation - unintended changes in behaviour which arise from a change in the perception of risk. As Richens et al. describe it, introduction of a safety device could lead to a lowered perception of risk; the rewards of risk-taking are subsequently heightened and an increase in risky behaviour may result (Richens et al., 2000). This is a prime concern as we develop new biomedical HIV prevention tools.

There is currently a move towards the development, assessment and implementation of combination approaches to HIV prevention which will provide a combination of the effective interventions outlined in this chapter. Future research will focus on determining the most appropriate and effective elements for inclusion in combination packages targeted at different vulnerable population groups and risk profiles (i.e. single women, single men, couples, and young people). The combination approach may also require revision of traditional mechanisms for delivery of primary health care, particularly in resource-limited settings, since this will likely be the most feasible venue in which to introduce such integrated care options.

Despite recent successes in the HIV prevention field (microbicides and oral PrEP), there are numerous implementation challenges ahead. Confirmation of the positive results will be necessary before these new prevention modalities can be widely rolled out, whether that be alone or in combination with other interventions. However, there is now renewed hope that biomedical intervention coupled with behaviour change may turn the tide against new HIV infections worldwide.

\section{References}

Abdala, N., Gleghorn, A.A., Carney, J.M. \& Heimer, R. (2001). Can HIV-1-contaminated syringes be disinfected?: Implications for transmission among injection drug users. Journal of Acquired Immune Deficiency Syndromes 28, 5: 487-494.

Abdala, N., Stephens, P.C., Griffith, B.P. \& Heimer, R. (1999). Survival of HIV-1 in syringes. Journal of Acquired Immune Deficiency Syndromes 20, 1: 73-80. 
Abdool Karim, Q., Abdool Karim, S.S., Frohlich, J.A., Grobler, A.C., Baxter, C., Mansoor, L.E., Kharsany, A.B.M., Sibeko, S., Mlisana, K.P., Omar, Z., Gengiah, T.N., Maarschalk, S., Arulappan, N., Mlotshwa, M., Morris, L., Taylor, D. \& on behalf of the CAPRISA 004 Trial Group (2010). Effectiveness and safety of tenofovir gel, an antiretroviral microbicide, for the prevention of HIV infection in women. Science 329, 5996: 1168-1174

Abdool Karim, S.S., Richardson, B.A., Ramjee, G., Hoffman, I.F., Chirenje, Z.M., Taha, T., Kapina, M., Maslankowski, L., Coletti, A., Profy, A., Moench, T.R., PiwowarManning, E., Mâsse, B., Hillier, S.L., Soto-Torres, L. \& on behalf of the HIV Prevention Trials Network 035 Study Team (2011). Safety and effectiveness of BufferGel and 0.5\% PRO2000 gel for the prevention of HIV infection in women. AIDS ePublished Ahead of Print: 10.1097/QAD.1090b1013e32834541d32834549.

Ahmed, S., Lutalo, T., Wawer, M., Serwadda, D., Sewankambo, N.K., Nalugoda, F., Makumbi, F., Wabwire-Mangen, F., Kiwanuka, N., Kigozi, G., Kiddugavu, M. \& Gray, R. (2001). HIV incidence and sexually transmitted disease prevalence associated with condom use: a population study in Rakai, Uganda. AIDS 15, 16: 2171-2179.

Amara, R.R., Villinger, F., Altman, J.D., Lydy, S.L., O'Neil, S.P., Staprans, S.I., Montefiori, D.C., Xu, Y., Herndon, J.G., Wyatt, L.S., Candido, M.A., Kozyr, N.L., Earl, P.L., Smith, J.M., Ma, H.-L., Grimm, B.D., Hulsey, M.L., Miller, J., McClure, H.M., McNicholl, J.M., Moss, B. \& Robinson, H.L. (2001). Control of a mucosal challenge and prevention of AIDS by a multiprotein DNA/MVA vaccine. Science 292, 5514: 69-74.

Aravantinou, M., Kenney, J., Singer, R., Gettie, A., Lifson, J., Piatak Jr, M., FernandezRomero, J., Zydowsky, T., Blanchard, J. \& Robbiani, M. (2010). Temporal association of protection by Carraguard-based gels containing MIV-150 after single versus repeated vaginal application in macaques [Abstract no. 38]. Microbicides 2010, Pittsburgh, Pennsylvania, USA, 22-25 May 2010.

Atkinson, W.L., Pickering, L.K., Schwartz, B., Weniger, B.G., Iskander, J.K. \& Watson, J.C. (2002). General recommendations on immunization. Morbidity and Mortality Weekly Report 51, RR02: 1-36.

Auvert, B., Taljaard, D., Lagarde, E., Sobngwi-Tambekou, J., Sitta, R. \& Puren, A. (2005). Randomized, controlled intervention trial of male circumcision for reduction of HIV infection risk: The ANRS 1265 trial. PLoS Medicine 2, 11: e298.

Bailey, R., Moses, S., Parker, C., Agot, K., Maclean, I., Krieger, J., Williams, C., Campbell, R. \& Ndinya-Achola, J. (2007). Male circumcision for HIV prevention in young men in Kisumu, Kenya: A randomised controlled trial. The Lancet 369, 9562: 643-656.

Beksinska, M.E., Rees, H.V., Dickson-Tetteh, K.E., Mqoqi, N., Kleinschmidt, I. \& McIntyre, J.A. (2001). Structural integrity of the female condom after multiple uses, washing, drying, and re-lubrication. Contraception 63, 1: 33-36.

Buchbinder, S., Mehrotra, D., Duerr, A., Fitzgerald, D., Mogg, R., Li, D., Gilbert, P., Lama, J., Marmor, M. \& Delrio, C. (2008). Efficacy assessment of a cell-mediated immunity HIV-1 vaccine (the Step Study): A double-blind, randomised, placebo-controlled, test-of-concept trial. The Lancet 372, 9653: 1881-1893. 
Buckheit Jr, R.W., Watson, K.M., Morrow, K.M. \& Ham, A.S. (2010). Development of topical microbicides to prevent the sexual transmission of HIV. Antiviral Research 85, 1: 142158.

Burton, D.R., Desrosiers, R.C., Doms, R.W., Koff, W.C., Kwong, P.D., Moore, J.P., Nabel, G.J., Sodroski, J., Wilson, I.A. \& Wyatt, R.T. (2004). HIV vaccine design and the neutralizing antibody problem. Nature Immunology 5, 3: 233-236.

Carey, R.F., Herman, W.A., Retta, S.M., Rinaldi, J.E., Herman, B.A. \& Athey, T.W. (1992). Effectiveness of latex condoms as a barrier to human immunodeficiency virus-sized particles under conditions of simulated use. Sexually Transmitted Diseases 19, 4: 230234.

Celum, C., Wald, A., Hughes, J., Sanchez, J., Reid, S., Delany-Moretlwe, S., Cowan, F., Casapia, M., Ortiz, A. \& Fuchs, J. (2008). Effect of aciclovir on HIV-1 acquisition in herpes simplex virus 2 seropositive women and men who have sex with men: A randomised, double-blind, placebo-controlled trial. The Lancet 371, 9630: 2109-2119.

Celum, C., Wald, A., Lingappa, J.R., Magaret, A.S., Wang, R.S., Mugo, N., Mujugira, A., Baeten, J.M., Mullins, J.I., Hughes, J.P., Bukusi, E.A., Cohen, C.R., Katabira, E., Ronald, A., Kiarie, J., Farquhar, C., Stewart, G.J., Makhema, J., Essex, M., Were, E., Fife, K.H., de Bruyn, G., Gray, G.E., McIntyre, J.A., Manongi, R., Kapiga, S., Coetzee, D., Allen, S., Inambao, M., Kayitenkore, K., Karita, E., Kanweka, W., Delany, S., Rees, H., Vwalika, B., Stevens, W., Campbell, M.S., Thomas, K.K., Coombs, R.W., Morrow, R., Whittington, W.L.H., McElrath, M.J., Barnes, L., Ridzon, R., Corey, L. \& the Partners in Prevention HSV/HIV Transmission Study Team (2010). Acyclovir and transmission of HIV-1 from persons infected with HIV1 and HSV-2. New England Journal of Medicine 362, 5: 427-439.

Chigwedere, P., Seage, G.R., Lee, T.-H. \& Essex, M. (2008). Efficacy of antiretroviral drugs in reducing mother-to-child transmission of HIV in Africa: A meta-analysis of published clinical trials. AIDS Research and Human Retroviruses 24, 6: 827-837.

Chimbiri, A.M. (2007). The condom is an 'intruder' in marriage: Evidence from rural Malawi. Social Science and Medicine 64, 5: 1102-1115.

Chun, T.-W., Engel, D., Berrey, M.M., Shea, T., Corey, L. \& Fauci, A.S. (1998). Early establishment of a pool of latently infected, resting CD4+ T cells during primary HIV-1 infection. Proceedings of the National Academy of Sciences of the United States of America 95, 15: 8869-8873.

Connor, E.M., Sperling, R.S., Gelber, R., Kiselev, P., Scott, G., O'Sullivan, M.J., VanDyke, R., Bey, M., Shearer, W., Jacobson, R.L., Jimenez, E., O'Neill, E., Bazin, B., Delfraissy, J.F., Culnane, M., Coombs, R., Elkins, M., Moye, J., Stratton, P., Balsley, J. \& The Pediatric AIDS Clinical Trials Group Protocol 076 Study Group (1994). Reduction of maternal-infant transmission of human immunodeficiency virus type 1 with zidovudine treatment. New England Journal of Medicine 331, 18: 1173-1180.

Coovadia, H., Jewkes, R., Barron, P., Sanders, D. \& McIntyre, D. (2009). The health and health system of South Africa: Historical roots of current public health challenges. The Lancet 374, 9692: 817-834.

Copenhaver, M.M., Johnson, B.T., Lee, I.C., Harman, J.J. \& Carey, M.P. (2006). Behavioral HIV risk reduction among people who inject drugs: Meta-analytic evidence of efficacy. Journal of Substance Abuse Treatment 31, 2: 163-171. 
Crosby, R.A. \& Holtgrave, D.R. (2006). Will sexual risk behaviour increase after being vaccinated for AIDS? International Journal of STD \& AIDS 17, 3: 180-184.

D'Cruz, O.J. \& Uckun, F.M. (2006). Dawn of non-nucleoside inhibitor-based anti-HIV microbicides. Journal of Antimicrobial Chemotherapy 57, 3: 411-423.

Davis, K.R. \& Weller, S.C. (1999). The effectiveness of condoms in reducing heterosexual transmission of HIV. Family Planning Perspectives 31, 6: 272-279.

del Mar Pujades Rodríguez, M., Obasi, A., Mosha, F., Todd, J., Brown, D., Changalucha, J., Mabey, D., Ross, D., Grosskurth, H. \& Hayes, R. (2002). Herpes simplex virus type 2 infection increases HIV incidence: A prospective study in rural Tanzania. AIDS 16, 3: 451-462.

Dhawan, D. \& Mayer, K.H. (2006). Microbicides to prevent HIV transmission: Overcoming obstacles to chemical barrier protection. The Journal of Infectious Diseases 193, 1: 3644.

Dinh, M.H., McRaven, M.D., Kelley, Z., Penugonda, S. \& Hope, T.J. (2010). Keratinization of the adult male foreskin and implications for male circumcision. AIDS 24, 6: 899-906

Doweiko, H.E. (2009). Concepts of Chemical Dependancy (Seventh edition), Brooks/Cole Cengage Learning, Belmont.

Drew, W.L., Blair, M., Miner, R.C. \& Conant, M. (1990). Evaluation of the virus permeability of a new condom for women. Sexually Transmitted Diseases 17, 2: 110-112.

Dunn, P.M. (1996). Dr Edward Jenner (1749-1823) of Berkeley, and vaccination against smallpox. Archives of Disease in Childhood - Fetal and Neonatal Edition 74, 1: F77-F78.

Epstein, H. (2008). AIDS and the irrational. BMJ 337: a2638.

Evans, A., Fletcher, P., Herrera, C. \& Shattock, R. (2010). Protease inhibitors darunavir, lopinavir and ritonavir as potential microbicides [Abstract no. 24]. Microbicides 2010, Pittsburgh, Pennsylvania, USA, 22-25 May 2010.

Feldblum, P., Adeiga, A., Bakare, R., Wevill, S., Lendvay, A., Obadaki, F., Olayemi, M., Wang, L., Nanda, K. \& Rountree, W. (2008). SAVVY vaginal gel (C31G) for prevention of HIV infection: A randomized controlled trial in Nigeria. PLoS One 3, 1: e1471.

Fleming, D.T. \& Wasserheit, J.N. (1999). From epidemiological synergy to public health policy and practice: The contribution of other sexually transmitted diseases to sexual transmission of HIV infection. Sexually Transmitted Infections 75, 1: 3-17.

Fletcher, P., Herrera, C., Armanasco, N., Nuttall, J., Romano, J. \& Shattock, R. (2010). AntiHIV activity of the candidate microbicide maraviroc, a CCR5 receptor antagonist [Abstract no. 21]. Microbicides 2010, Pittsburgh, Pennsylvania, USA, 22-25 May 2010.

Flynn, N.M., Forthal, D.N., Harro, C.D., Judson, F.N., Mayer, K.H., Para, M.F. \& rgp, H.I.V.V.S.G. (2005). Placebo-controlled phase 3 trial of a recombinant glycoprotein 120 vaccine to prevent HIV-1 infection. The Journal of Infectious Diseases 191, 5: 654665.

Foss, A.M., Watts, C.H., Vickerman, P. \& Heise, L. (2004). Condoms and prevention of HIV. BMJ 329, 7459: 185-186.

Freeman, E., Weiss, H., Glynn, J., Cross, P., Whitworth, J. \& Hayes, R. (2006). Herpes simplex virus 2 infection increases HIV acquisition in men and women: Systematic review and meta-analysis of longitudinal studies. AIDS 20, 1: 73-83.

Gerra, G., Saenz, E., Busse, A., Maremmani, I., Ciccocioppo, R., Zaimovic, A., Gerra, M.L., Amore, M., Manfredini, M., Donnini, C. \& Somaini, L. (2011). Supervised daily 
consumption, contingent take-home incentive and non-contingent take-home in methadone maintenance. Progress in Neuro-Psychopharmacology and Biological Psychiatry 35, 2: 483-489.

Ghys, P.D., Diallo, M.O., Ettiègne-Traoré, V., Satten, G.A., Anoma, C.K., Maurice, C., Kadjo, J.-C., Coulibaly, I.-M., Wiktor, S.Z., Greenberg, A.E. \& Laga, M. (2001). Effect of interventions to control sexually transmitted disease on the incidence of HIV infection in female sex workers. AIDS 15, 11: 1421-1431.

Gilead (2008). Emtriva package insert.

Gilead (2010). Viread package insert.

Girard, M.P., Osmanov, S.K. \& Kieny, M.P. (2006). A review of vaccine research and development: The human immunodeficiency virus (HIV). Vaccine 24, 19: 4062-4081.

Grant, R.M., Lama, J.R., Anderson, P.L., McMahan, V., Liu, A.Y., Vargas, L., Goicochea, P., Casapía, M., Guanira-Carranza, J.V., Ramirez-Cardich, M.E., Montoya-Herrera, O., Fernández, T., Veloso, V.G., Buchbinder, S.P., Chariyalertsak, S., Schechter, M., Bekker, L.-G., Mayer, K.H., Kallás, E.G., Amico, K.R., Mulligan, K., Bushman, L.R., Hance, R.J., Ganoza, C., Defechereux, P., Postle, B., Wang, F., McConnell, J.J., Zheng, J.-H., Lee, J., Rooney, J.F., Jaffe, H.S., Martinez, A.I., Burns, D.N. \& Glidden, D.V. (2010). Preexposure chemoprophylaxis for HIV prevention in men who have sex with men. New England Journal of Medicine 363, 27: 2587-2599.

Gray, G., Allen, M., Bekker, L., Churchyard, G., Mlisana, K., Nchabeleng, M., Moodie, F., Metch, B. \& Cassis-Ghavami, F. (2008). Results from the Phambili (HVTN 503) study: A multicenter double-blind placebo-controlled Phase IIB test-of-concept study to evaluate the safety and efficacy of the MRKad5 HIV-1 gag/pol/nef vaccine in HIV-1 uninfected South Africans. AIDS Vaccine, Cape Town, South Africa, 13-16 Ocober 2008.

Gray, R., Kigozi, G., Serwadda, D., Makumbi, F., Watya, S., Nalugoda, F., Kiwanuka, N., Moulton, L., Chaudhary, M. \& Chen, M. (2007). Male circumcision for HIV prevention in men in Rakai, Uganda: A randomised trial. The Lancet 369, 9562: 657666.

Grosskurth, H., Gray, R., Hayes, R., Mabey, D. \& Wawer, M. (2000). Control of sexually transmitted diseases for HIV-1 prevention: Understanding the implications of the Mwanza and Rakai trials. The Lancet 355, 9219: 1981-1987.

Grosskurth, H., Todd, J., Mwijarubi, E., Mayaud, P., Nicoll, A., ka-Gina, G., Newell, J., Mabey, D., Hayes, R., Mosha, F., Senkoro, K., Changalucha, J., Klokke, A. \& Mugeye, K. (1995). Impact of improved treatment of sexually transmitted diseases on HIV infection in rural Tanzania: Randomised controlled trial. The Lancet 346, 8974: 530-536.

Gunderson, E.W. \& Fiellin, D.A. (2008). Office-based maintenance treatment of opioid dependence: How does it compare with traditional approaches? CNS Drugs 22: 99111.

Halperin, D. \& Epstein, H. (2007). Why is HIV prevalence so severe in southern Africa? The role of multiple concurrent partnerships and lack of male circumcision: Implications for AIDS prevention. The Southern African Journal of HIV Medicine 8: 1925.

Hargreaves, J.R., Morison, L.A., Kim, J.C., Busza, J., Phetla, G., Porter, J.D., Watts, C. \& Pronyk, P.M. (2009). Characteristics of sexual partnerships, not just of individuals, 
are associated with condom use and recent HIV infection in rural South Africa. AIDS Care 21, 8: 1058-1070.

Herrera, C., Armanasco, N., Fletcher, P., Nuttall, J., Romano, J. \& Shattock, R. (2010). Combinations of maraviroc and reverse transcriptase inhibitors as potential microbicides [Abstract no. 22]. Microbicides 2010, Pittsburgh, Pennsylvania, USA, 22-25 May 2010.

Hladik, F. \& Hope, T. (2009). HIV infection of the genital mucosa in women. Current HIV/AIDS Reports 6, 1: 20-28.

Ho, G.Y.F., Burk, R.D., Klein, S., Kadish, A.S., Chang, C.J., Palan, P., Basu, J., Tachezy, R., Lewis, R. \& Romney, S. (1995). Persistent genital Human Papillomavirus infection as a risk factor for persistent cervical dysplasia. Journal of the National Cancer Institute 87, 18: 1365-1371.

Hoenig, L.J. (1986). Triumph and controversy: Pasteur's preventive treatment of rabies as reported in JAMA. Archives of Neurology 43, 4: 397-399.

Holmes, K., Levine, R. \& Weaver, M. (2004). Effectiveness of condoms in preventing sexually transmitted infections. Bulletin of the World Health Organization 82: 454-461.

Holtzman, D., Barry, V., Ouellet, L.J., Jarlais, D.C.D., Vlahov, D., Golub, E.T., Hudson, S.M. \& Garfein, R.S. (2009). The influence of needle exchange programs on injection risk behaviors and infection with hepatitis $C$ virus among young injection drug users in select cities in the United States, 1994-2004. Preventive Medicine 49, 1: 68-73.

Hu, S.-L., Klaniecki, J., Dykers, T., Sridhar, P. \& Travis, B.M. (1991). Neutralizing antibodies against HIV-1 BRU and SF2 isolates generated in mice immunized with recombinant vaccinia virus expressing HIV-1 (BRU) envelope glycoproteins and boosted with homologous gp160. AIDS Research and Human Retroviruses 7, 7: 615620.

Hunter, M. (2007). The changing political economy of sex in South Africa: The significance of unemployment and inequalities to the scale of the AIDS pandemic. Social Science and Medicine 64, 3: 689-700.

Hurley, S.F., Jolley, D.J. \& Kaldor, J.M. (1997). Effectiveness of needle-exchange programmes for prevention of HIV infection. The Lancet 349, 9068: 1797-1800.

Huskens, D., Vermeire, K., Profy, A.T. \& Schols, D. (2009). The candidate sulfonated microbicide, PRO 2000, has potential multiple mechanisms of action against HIV-1. Antiviral Research 84, 1: 38-47.

Jasinski, D.R., Pevnick, J.S. \& Griffith, J.D. (1978). Human pharmacology and abuse potential of the analgesic buprenorphine: A potential agent for treating narcotic addiction. Archives of General Psychiatry 35, 4: 501-516.

Jennings, R. \& Clegg, A. (1993). The inhibitory effect of spermicidal agents on replication of HSV-2 and HIV-1 in-vitro. Journal of Antimicrobial Chemotherapy 32, 1: 71-82.

Johnston, M. \& Fauci, A. (2007). An HIV vaccine--evolving concepts. New England Journal of Medicine 356, 20: 2073-2081.

Johnston, M.I. \& Fauci, A.S. (2008). An HIV vaccine-challenges and prospects. New England Journal of Medicine 359, 9: 888-890.

Kamali, A., Quigley, M., Nakiyingi, J., Kinsman, J., Kengeya-Kayondo, J., Gopal, R., Ojwiya, A., Hughes, P., Carpenter, L. \& Whitworth, J. (2003). Syndromic management of sexually-transmitted infections and behaviour change interventions on 
transmission of HIV-1 in rural Uganda: A community randomised trial. The Lancet 361, 9358: 645-652.

Kaul, R., Kimani, J., Nagelkerke, N.J., Fonck, K., Ngugi, E.N., Keli, F., MacDonald, K.S., Maclean, I.W., Bwayo, J.J., Temmerman, M., Ronald, A.R. \& Moses, S. (2004). Monthly antibiotic chemoprophylaxis and incidence of sexually transmitted infections and HIV-1 infection in Kenyan sex workers: A randomized controlled trial. JAMA 291, 21: 2555-2562.

Kenney, J., Aravantinou, M., Singer, R., Hsu, M., Rodriguez, A., Kizima, L., Abraham, C.J., Menon, R., Seidor, S., Chudolij, A., Gettie, A., Blanchard, J., Lifson, J.D., Piatak, M., Jr., Fernández-Romero, J.A., Zydowsky, T.M. \& Robbiani, M. (2011). An antiretroviral/zinc combination gel provides 24 hours of complete protection against vaginal SHIV infection in macaques. PLoS One 6, 1: e15835.

Kigozi, G., Wawer, M., Ssettuba, A., Kagaayi, J., Nalugoda, F., Watya, S., Mangen, F.W., Kiwanuka, N., Bacon, M.C., Lutalo, T., Serwadda, D. \& Gray, R.H. (2009). Foreskin surface area and HIV acquisition in Rakai, Uganda (size matters). AIDS 23, 16: 2209-2213

Klausner, J.D., Wamai, R.G., Bowa, K., Agot, K., Kagimba, J. \& Halperin, D.T. (2008). Is male circumcision as good as the HIV vaccine we've been waiting for? Future HIV Therapy 2, 1: 1-7.

Laga, M., Schwärtlander, B., Pisani, E., Sow, P.S. \& Caraël, M. (2001). To stem HIV in Africa, prevent transmission to young women. AIDS 15: 931-934.

Lagakos, S.W. \& Gable, A.R. (2008). Challenges to HIV prevention -- seeking effective measures in the absence of a vaccine. New England Journal of Medicine 358, 15: 15431545.

Lawson, M.L., Macaluso, M., Duerr, A., Hortin, G., Hammond, K.R., Blackwell, R., Artz, L. \& Bloom, A. (2003). Partner characteristics, intensity of the intercourse, and semen exposure during use of the female condom. American Journal of Epidemiology 157, 4: 282-288.

Letvin, N.L., Mascola, J.R., Sun, Y., Gorgone, D.A., Buzby, A.P., Xu, L., Yang, Z.-y., Chakrabarti, B., Rao, S.S., Schmitz, J.E., Montefiori, D.C., Barker, B.R., Bookstein, F.L. \& Nabel, G.J. (2006). Preserved CD4+ central memory T cells and survival in vaccinated SIV-challenged monkeys. Science 312, 5779: 1530-1533.

Lytle, D.C., Routson, L.B., Seaborn, G.B., Dixon, L.G., Bushar, H.F. \& Cyr, H.W. (1997). An in vitro evaluation of condoms as barriers to a small virus. Sexually Transmitted Diseases 24, 3: 161-164.

Macaluso, M., Lawson, M.L., Hortin, G., Duerr, A., Hammond, K.R., Blackwell, R. \& Bloom, A. (2003). Efficacy of the female condom as a barrier to semen during intercourse. American Journal of Epidemiology 157, 4: 289-297.

MacDonald, M., Law, M., Kaldor, J., Hales, J. \& J. Dore, G. (2003). Effectiveness of needle and syringe programmes for preventing HIV transmission. International Journal of Drug Policy 14, 5-6: 353-357.

Mackie, N. \& Coker, R. (2000). Post-exposure prophylaxis following non-occupational exposure to HIV: Risks, uncertainties, and ethics. International Journal of STD $\mathcal{E}$ AIDS 11, 7: 424-427.

Maharaj, P. \& Cleland, J. (2004). Condom use within marital and cohabiting partnerships in KwaZulu-Natal, South Africa. Studies in Family Planning 35, 2: 116-124. 
Malcolm, R.K., Edwards, K.-L., Kiser, P., Romano, J. \& Smith, T.J. (2010). Advances in microbicide vaginal rings. Antiviral Research 88, Supplement 1: S30-S39.

Marais, D., Gawarecki, D., Rutenberg, N., Allan, B., Ahmed, K., Altini, L., Cassim, N., Gopolang, F., Hoffman, M. \& Williamson, A.-L. (2010). Carraguard, a vaginal microbicide, protects women against HPV infection. 26th International Papillomavirus Conference \& Clinical and Public Health Workshops, Montréal, Canada, 3-8 July 2010.

Markel, H. (2005). The search for effective HIV vaccines. New England Journal of Medicine 353, 8: 753-757.

Mâsse, B., Boily, M.-C., Dimitrov, D. \& Desai, K. (2009). Efficacy dilution in randomized placebo-controlled vaginal microbicide trials. Emerging Themes in Epidemiology 6, 1: 5 .

McCoombe, S.G. \& Short, R.V. (2006). Potential HIV-1 target cells in the human penis. AIDS 20, 11: 1491-1495

Mendelson, J., Jones, R.T., Fernandez, I., Welm, S., Melby, A.K. \& Baggott, M.J. (1996). Buprenorphine and naloxone interactions in opiate-dependent volunteers. Clinical Pharmacology and Therapeutics 60, 1: 105-114.

Mesquita, P.M.M., Cheshenko, N., Wilson, S.S., Mhatre, M., Guzman, E., Fakioglu, E., Keller, M.J. \& Herold, B.C. (2009). Disruption of tight junctions by cellulose sulfate facilitates HIV infection: Model of microbicide safety. The Journal of Infectious Diseases 200, 4: 599-608.

Metzger, D.S. \& Navaline, H. (2003). Human immunodeficiency virus prevention and the potential of drug abuse treatment. Clinical Infectious Diseases 37, Supplement 5: S451-S456.

Metzger, D.S., Woody, G.E., McLellan, A.T., O'Brien, C.P., Druley, P., Navaline, H., DePhilippis, D., Stolley, P. \& Abrutyn, E. (1993). Human immunodeficiency virus seroconversion among intravenous drug users in- and out-of-treatment: An 18month prospective follow-up. Journal of Acquired Immune Deficiency Syndromes 6, 9: 1049-1056.

Miller, C., Alexander, N., Gettie, A., Hendrickx, A. \& Marx, P. (1992). The effect of contraceptives containing nonoxynol-9 on the genital transmission of simian immunodeficiency virus in rhesus macaques. Fertility and Sterility 57, 5: 1126-1128.

Millett, G.A., Flores, S.A., Marks, G., Reed, J.B. \& Herbst, J.H. (2008). Circumcision status and risk of HIV and sexually transmitted infections among men who have sex with men. JAMA 300, 14: 1674-1684.

Moench, T.R., Whaley, K.J., Mandrell, T.D., Bishop, B.D., Witt, C.J. \& Cone, R.A. (1993). The cat/feline immunodeficiency virus model for transmucosal transmission of AIDS: Nonoxynol-9 contraceptive jelly blocks transmission by an infected cell inoculum. AIDS 7, 6: 797-802.

Ndesendo, V., Pillay, V., Choonara, Y., Buchmann, E., Bayever, D. \& Meyer, L. (2008). A review of current intravaginal drug delivery approaches employed for the prophylaxis of HIV/AIDS and prevention of sexually transmitted infections. AAPS PharmSciTech 9, 2: 505-520.

Newman, P.A., Duan, N., Rudy, E.T. \& Johnston-Roberts, K. (2004). HIV risk and prevention in a post-vaccine context. Vaccine 22, 15-16: 1954-1963. 
Nobbenhuis, M.A.E., Walboomers, J.M.M., Helmerhorst, T.J.M., Rozendaal, L., Remmink, A.J., Risse, E.K.J., van der Linden, H.C., Voorhorst, F.J., Kenemans, P. \& Meijer, C.J.L.M. (1999). Relation of human papilloma virus status to cervical lesions and consequences for cervical-cancer screening: A prospective study. The Lancet 354, 9172: 20-25.

Padian, N., van der Straten, A., Ramjee, G., Chipato, T., de Bruyn, G., Blanchard, K., Shiboski, S., Montgomery, E., Fancher, H. \& Cheng, H. (2007). Diaphragm and lubricant gel for prevention of HIV acquisition in southern African women: A randomised controlled trial. The Lancet 370, 9583: 251-261.

Padian, N.S., Buvé, A., Balkus, J., Serwadda, D. \& Cates Jr, W. (2008). Biomedical interventions to prevent HIV infection: Evidence, challenges, and way forward. The Lancet 372, 9638: 585-599.

Park, L.S., Siraprapasiri, T., Peerapatanapokin, W., Manne, J., Niccolai, L. \& Kunanusont, C. (2010). HIV transmission rates in Thailand: Evidence of HIV prevention and transmission decline. Journal of Acquired Immune Deficiency Syndromes 54, 4: 430-436

Patterson, B.K., Landay, A., Siegel, J.N., Flener, Z., Pessis, D., Chaviano, A. \& Bailey, R.C. (2002). Susceptibility to human immunodeficiency virus-1 infection of human foreskin and cervical tissue grown in explant culture. American Journal of Pathology 161, 3: 867-873.

Patton, D.L., Sweeney, Y.T. \& Paul, K.J. (2009). A summary of preclinical topical microbicide rectal safety and efficacy evaluations in a pigtailed macaque model. Sexually Transmitted Diseases 36, 6: 350-356.

Paxton, L., Hope, T. \& Jaffe, H. (2007). Pre-exposure prophylaxis for HIV infection: What if it works? The Lancet 370, 9581: 89-93.

Peters, A., Jansen, W. \& van Driel, F. (2010). The female condom: The international denial of a strong potential. Reproductive Health Matters 18, 35: 119-128.

Peterson, L., Nanda, K., Opoku, B.K., Ampofo, W.K., Owusu-Amoako, M., Boakye, A.Y., Rountree, W., Troxler, A., Dominik, R., Roddy, R. \& Dorflinger, L. (2007). SAVVY® (C31G) gel for prevention of HIV infection in women: A phase 3, double-blind, randomized, placebo-controlled trial in Ghana. PLoS One 2, 12: e1312.

Pilcher, C.D., Tien, H.C., Eron Jr, J.J., Vernazza, P.L., Leu, S.Y., Stewart, P.W., Goh, L.E. \& Cohen, M.S. (2004). Brief but efficient: Acute HIV infection and the sexual transmission of HIV. The Journal of Infectious Diseases 189, 10: 1785-1792.

Pinkerton, S. \& Abramson, P.R. (1997). Effectiveness of condoms in preventing HIV transmission. Social Science and Medicine 44, 9: 1303-1312.

Pitisuttithum, P., Gilbert, P., Gurwith, M., Heyward, W., Martin, M., van Griensven, F., Hu, D., Tappero, J. \& Choopanya, K. (2006). Randomized, double-blind, placebocontrolled efficacy trial of a bivalent recombinant glycoprotein 120 HIV-1 vaccine among injection drug users in Bangkok, Thailand. The Journal of Infectious Diseases 194, 12: 1661-1671.

Polsky, B., Baron, P., Gold, J.M., Smith, J., Jensen, R. \& Armstrong, D. (1988). In vitro inactivation of HIV-1 by contraceptive sponge containing nonoxynol-9. The Lancet 331, 8600: 1456-1456.

Pudney, J., Quayle, A.J. \& Anderson, D.J. (2005). Immunological microenvironments in the human vagina and cervix: Mediators of cellular immunity are concentrated in the cervical transformation zone. Biology of Reproduction 73, 6: 1253-1263. 
Ramjee, G., Kamali, A. \& McCormack, S. (2010). The last decade of microbicide clinical trials in Africa: From hypothesis to facts. AIDS 24, Suppl 4: S40-S49.

Ramjee, G., Kapiga, S., Weiss, S., Peterson, L., Leburg, C., Kelly, C., Mâsse, B. \& HPTN Study Team (2008). The value of site preparedness studies for future implementation of phase 2/IIb/III HIV prevention trials - Experience from the HPTN 055 study. Journal of Acquired Immune Deficiency Syndromes 47, 1: 93-100.

Ramjee, G., van der Straten, A., Chipato, T., de Bruyn, G., Blanchard, K., Shiboski, S., Cheng, H., Montgomery, E., Padian, N. \& for the, M.t. (2008). The diaphragm and lubricant gel for prevention of cervical sexually transmitted infections: Results of a randomized controlled trial. PLoS One 3, 10: e3488.

Rebbapragada, A. \& Kaul, R. (2007). More than their sum in your parts: The mechanisms that underpin the mutually advantageous relationship between HIV and sexually transmitted infections. Drug Discovery Today: Disease Mechanisms 4, 4: 237-246.

Rerks-Ngarm, S., Pitisuttithum, P., Nitayaphan, S., Kaewkungwal, J., Chiu, J., Paris, R., Premsri, N., Namwat, C., de Souza, M., Adams, E., Benenson, M., Gurunathan, S., Tartaglia, J., McNeil, J.G., Francis, D.P., Stablein, D., Birx, D.L., Chunsuttiwat, S., Khamboonruang, C., Thongcharoen, P., Robb, M.L., Michael, N.L., Kunasol, P., Kim, J.H. \& the MOPH-TAVEG Investigators (2009). Vaccination with ALVAC and AIDSVAX to prevent HIV-1 infection in Thailand. New England Journal of Medicine 361, 23: 2209-2220.

Richens, R., Imrie, J. \& Copas, A. (2000). Condoms and seat belts: The parallels and the lessons. The Lancet 355, 9201: 400-403.

Richman, D.D., Wrin, T., Little, S.J. \& Petropoulos, C.J. (2003). Rapid evolution of the neutralizing antibody response to HIV type 1 infection. Proceedings of the National Academy of Sciences of the United States of America 100, 7: 4144-4149.

Rojanapithayakorn, W. \& Hanenberg, R. (1996). The 100\% condom program in Thailand. AIDS 10, 1: 1-8.

Ruiz, P., Strain, E.C. \& Langrod, J. (2007). The Substance Abuse Handbook Lippincott Williams \& Wilkins, Philadelphia.

Shapshak, P., McCoy, C.B., Shah, S.M., Page, J.B., Rivers, J.E., Weatherby, N.L., Chitwood, D.D. \& Mash, D.C. (1994). Preliminary laboratory studies of inactivation of HIV-1 in needles and syringes containing infected blood using undiluted household bleach. Journal of Acquired Immune Deficiency Syndromes 7, 7: 754-759.

Skoler-Karpoff, S., Ramjee, G., Ahmed, K., Altini, L., Plagianos, M., Friedland, B., Govender, S., Dekock, A., Cassim, N. \& Palanee, T. (2008). Efficacy of Carraguard for prevention of HIV infection in women in South Africa: A randomised, doubleblind, placebo-controlled trial. The Lancet 372, 9654: 1977-1987.

Stein, Z.A. (1990). HIV prevention: The need for methods women can use. American Journal of Public Health 80, 4: 460-462.

Stoneburner, R. \& Low-Beer, D. (2004). Population-level HIV declines and behavioral risk avoidance in Uganda. Science 304, 5671: 714-718.

Templeton, D.J., Jin, F., Mao, L., Prestage, G.P., Donovan, B., Imrie, J., Kippax, S., Kaldor, J.M. \& Grulich, A.E. (2009). Circumcision and risk of HIV infection in Australian homosexual men. AIDS 23, 17: 2347-2351

Tobian, A.A.R., Serwadda, D., Quinn, T.C., Kigozi, G., Gravitt, P.E., Laeyendecker, O., Charvat, B., Ssempijja, V., Riedesel, M. \& Oliver, A.E. (2009). Male circumcision for 
the prevention of HSV-2 and HPV infections and syphilis. New England Journal of Medicine 360, 13: 1298-1309.

Tolley, E.E., Harrison, P.F., Goetghebeur, E., Morrow, K., Pool, R., Taylor, D., Tillman, S.N. \& van der Straten, A. (2009). Adherence and its measurement in phase 2/3 microbicide trials. AIDS and Behavior 14, 5: 1124-1136.

Toombs, J.D. \& Kral, L.A. (2005). Methadone treatment for pain states. American Family Physician 71, 7: 1353-1358.

UNAIDS (2010). Report on the global AIDS epidemic 2010 Joint United Nations Programme on HIV/AIDS, Geneva.

van Damme, L., Ramjee, G., Alary, M., Vuylsteke, B., Chandeying, V., Rees, H., Sirivongrangson, P., Tshibaka, L., Ettiegnetraore, V. \& Uaheowitchai, C. (2002). Effectiveness of COL-1492, a nonoxynol-9 vaginal gel, on HIV-1 transmission in female sex workers: A randomised controlled trial. The Lancet 360, 9338: 971-977.

Van Den Berg, C., Smit, C., Van Brussel, G., Coutinho, R. \& Prins, M. (2007). Full participation in harm reduction programmes is associated with decreased risk for human immunodeficiency virus and hepatitis $C$ virus: Evidence from the Amsterdam Cohort Studies among drug users. Addiction 102, 9: 1454-1462.

van Sighem, A., Gras, L., Reiss, P., Brinkman, K., de Wolf, F. \& on behalf of the ATHENA national observational cohort study (2010). Life expectancy of recently diagnosed asymptomatic HIV-infected patients approaches that of uninfected individuals. AIDS 24, 10: 1527-1535

Vermund, S.H., Allen, K.L. \& Karim, Q.A. (2009). HIV-prevention science at a crossroads: Advances in reducing sexual risk. Current Opinion in HIV and AIDS 4, 4: 266-273.

Vijayakumar, G., Mabude, Z., Smit, J., Beksinska, M. \& Lurie, M. (2006). A review of femalecondom effectiveness: Patterns of use and impact on protected sex acts and STI incidence. International Journal of STD \& AIDS 17, 10: 652-659.

Vlahov, D., Robertson, Angela M. \& Strathdee, Steffanie A. (2010). Prevention of HIV infection among injection drug users in resource-limited settings. Clinical Infectious Diseases 50, S3: S114-S121.

Walsh, S.L. \& Eissenberg, T. (2003). The clinical pharmacology of buprenorphine: Extrapolating from the laboratory to the clinic. Drug and Alcohol Dependence 70, 2, Supplement 1: S13-S27.

Warren, M. \& Philpott, A. (2003). Expanding safer sex options: Introducing the female condom into national programmes. Reproductive Health Matters 11, 21: 130-139.

Wasserheit, J.N. (1992). Epidemiological synergy: Interrelationships between human immunodeficiency virus infection and other sexually transmitted diseases. Sexually Transmitted Diseases 19, 2: 61-77.

Watson-Jones, D., Weiss, H.A., Rusizoka, M., Changalucha, J., Baisley, K., Mugeye, K., Tanton, C., Ross, D., Everett, D., Clayton, T., Balira, R., Knight, L., Hambleton, I., Le Goff, J., Belec, L. \& Hayes, R. (2008). Effect of herpes simplex suppression on incidence of HIV among women in Tanzania. New England Journal of Medicine 358, 15: 1560-1571.

Wawer, M., Makumbi, F., Kigozi, G., Serwadda, D., Watya, S., Nalugoda, F., Buwembo, D., Ssempijja, V., Kiwanuka, N. \& Moulton, L. (2009). Circumcision in HIV-infected men and its effect on HIV transmission to female partners in Rakai, Uganda: A randomised controlled trial. The Lancet 374, 9685: 229-237. 
Wawer, M.J., Tobian, A.A.R., Kigozi, G., Kong, X., Gravitt, P.E., Serwadda, D., Nalugoda, F., Makumbi, F., Ssempiija, V., Sewankambo, N., Watya, S., Eaton, K.P., Oliver, A.E., Chen, M.Z., Reynolds, S.J., Quinn, T.C. \& Gray, R.H. (2011). Effect of circumcision of HIV-negative men on transmission of human papillomavirus to HIV-negative women: A randomised trial in Rakai, Uganda. The Lancet 377, 9761: 209-218.

Weiss, H., Quigley, M. \& Hayes, R. (2000). Male circumcision and risk of HIV infection in sub-Saharan Africa: A systematic review and meta-analysis. AIDS 14, 15: 2361.

Weiss, H.A., Thomas, S.L., Munabi, S.K. \& Hayes, R.J. (2006). Male circumcision and risk of syphilis, chancroid, and genital herpes: A systematic review and meta-analysis. Sexually Transmitted Infections 82, 2: 101-110.

Weller, S. \& Davis-Beaty, K. (2002). Condom effectiveness in reducing heterosexual HIV transmission. Cochrane Database of Systematic Reviews, 1.

Wiessing, L., Likatavicius, G., Klempova, D., Hedrich, D., Nardone, A. \& Griffiths, P. (2009). Associations between availability and coverage of HIV-prevention measures and subsequent incidence of diagnosed HIV infection among injection drug users. American Journal of Public Health 99, 6: 1049-1052.

Williams, B.G., Lloyd-Smith, J.O., Gouws, E., Hankins, C., Getz, W.M., Hargrove, J., de Zoysa, I., Dye, C. \& Auvert, B. (2006). The potential impact of male circumcision on HIV in sub-Saharan Africa. PLoS Medicine 3, 7: e262.

Wodak, A. \& Cooney, A. (2005). Effectiveness of sterile needle and syringe programmes. The International journal on drug policy 16: 31-44.

Wyatt, R. \& Sodroski, J. (1998). The HIV-1 envelope glycoproteins: Fusogens, antigens, and immunogens. Science 280, 5371: 1884-1888. 


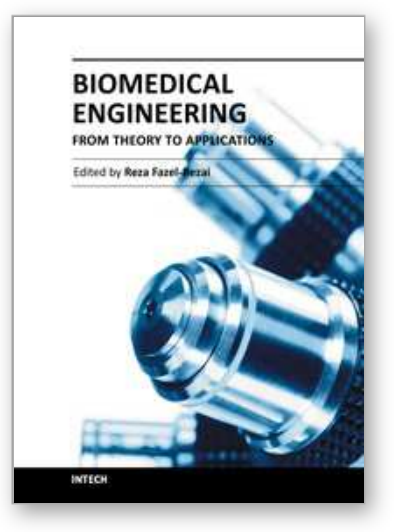

\author{
Biomedical Engineering - From Theory to Applications \\ Edited by Prof. Reza Fazel
}

ISBN 978-953-307-637-9

Hard cover, 486 pages

Publisher InTech

Published online 29, August, 2011

Published in print edition August, 2011

In all different areas in biomedical engineering, the ultimate objectives in research and education are to improve the quality life, reduce the impact of disease on the everyday life of individuals, and provide an appropriate infrastructure to promote and enhance the interaction of biomedical engineering researchers. This book is prepared in two volumes to introduce a recent advances in different areas of biomedical engineering such as biomaterials, cellular engineering, biomedical devices, nanotechnology, and biomechanics. It is hoped that both of the volumes will bring more awareness about the biomedical engineering field and help in completing or establishing new research areas in biomedical engineering.

\title{
How to reference
}

In order to correctly reference this scholarly work, feel free to copy and paste the following:

Gita Ramjee and Claire Whitaker (2011). Biomedical HIV Prevention, Biomedical Engineering - From Theory to Applications, Prof. Reza Fazel (Ed.), ISBN: 978-953-307-637-9, InTech, Available from:

http://www.intechopen.com/books/biomedical-engineering-from-theory-to-applications/biomedical-hivprevention

\section{INTECH}

open science | open minds

\section{InTech Europe}

University Campus STeP Ri Slavka Krautzeka 83/A 51000 Rijeka, Croatia Phone: +385 (51) 770447

Fax: +385 (51) 686166 www.intechopen.com

\section{InTech China}

Unit 405, Office Block, Hotel Equatorial Shanghai No.65, Yan An Road (West), Shanghai, 200040, China 中国上海市延安西路65号上海国际贵都大饭店办公楼405单元 Phone: +86-21-62489820

Fax: +86-21-62489821 
(C) 2011 The Author(s). Licensee IntechOpen. This chapter is distributed under the terms of the Creative Commons Attribution-NonCommercialShareAlike-3.0 License, which permits use, distribution and reproduction for non-commercial purposes, provided the original is properly cited and derivative works building on this content are distributed under the same license. 